\title{
ONKO KORKEAKOULUTUS AIKUISKASVATUSTA?
}

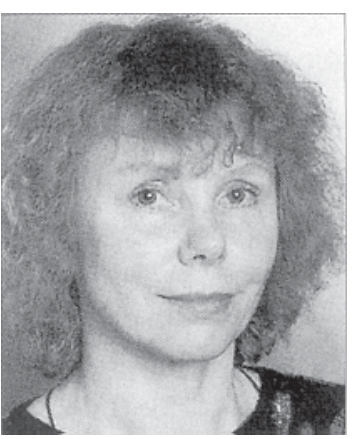

Anja Heikkinen
$\mathrm{M}$ itä hämärämmäksi jonkin ilmiön tai instituution merkitys tulee, sitä jyrkemmin ja ristiriitaisemmin sen pinnanmuodostukseen usein kiinnitytään. Yliopisto, korkeakoulutus ja aikuisuus ovat tästä hyviä esimerkkejä. Niin korkea-asteen kuin aikuisten koulutus ovat kansallisen ja ylikansallisen talous-, sosiaali- ja koulutuspolitiikan keskiössä. Aikuisuutta aktivoidaan moninaisin elinikäisen oppimisen ohjelmin, joissa sen määrittelijöiden päähuolena on alueensa houkuttelevuus ylikansallisen pääoman toimintakenttänä. Tähän arvokonseptiin ei sovi aikuisuus omaehtoisen kasvun ja oppimisen lähtökohtana. Vaikka aikuisten tietoyhteiskuntataidoista ja ammatillisesta osaamisesta ollaan huolissaan, kilpailukykyisellä eurooppalaisen korkeakoulutuksen alueella aikuisuus on ongelma. Opiskelijoiden läpivirtausta koulutusjärjestelmässä on Suomessa radikaalisti tehostettava, korkeakoulututkintojen yksilöille, kansantaloudelle ja yrityksille koituvaa hyötyä on lisättävä. Ihanneoppija minimoi omat ja yhteiskunnan koulutusinvestoinnit ja tupsahtaa työmarkkinoille nuorena, innovatiivisuutensa keskittyvänä, lisäarvoa tuottavana yrittäjäitsenä. Hänen päähuolensa on osaamisensa sekä tuotanto- ja kulutuskykynsä jatkuva päivittäminen hamaan vireään senioriteettiin saakka. Joustavuus- ja muutospuheesta huolimatta yliopistot ja korkeakoulut eivät toivota tervetulleiksi elämänpolullaan epävarmoja tai uusia aloituksia etsiviä ihmisiä "varsinaisiksi” opiskelijoiksi. Räätälöidyn ja maksullisen, usein työorganisaatioiden tarpeista määritellyn ”aikuiskoulutuksen” kohteiksi he sen sijaan ovat tervetulleita.

\section{1 ikuiskasvatuksen ja aikuiskasvatustieteen näkökulmasta aikuisuu-} tyksen korkeinta, aineellisista ehdoistaan vapaata astetta. Pohjoismaisen kansanopistoliikkeen ideologin N.F.S. Grundtvigin motiivina oli 1830-40luvuilla kansaisen vaihtoehdon kehittäminen "mustalle” ja "kuolleelle” yliopistolle. ”Saksalaisten kuvitelma, että elämä voidaan ja se pitää selittää, ennen kuin sitä on eletty, että se voidaan ja pitää luoda uudelleen oppineiden ihmisten aivoitusten mukaan, tekee kaikista kouluista tuhon ja kuoleman työpajoja, missä madot syövät elämää... (Minä) väitän, että koulusta tulee elämää hyödyttävä sivistyslaitos vain silloin, jos se ensinnäkin pitää päämääränään - ei sivistystä eikä omaa itseään - vaan elämän parasta. Toiseksi sen tulee nähdä elämä sellaisena kuin se todella on, ja yrittää valaista ja kehittää sen käytäntöä.” Suomalaisten kansanvalistajien ja -sivistäjien arvoissa kansaisuuteen liittyi taas vahvasti tieteellisen ja yhteiskunnallisen ajattelun edistyminen. Kansanopistojen tuli kasvattaa kansan luottamusmiehiä ja -naisia kaikilla elämänalueilla, Mikael Johnssonin (Soini- 
sen) sanoin "luotava se virkavallasta riippumaton, sivistynyt sääty, joka on kaikissa koettelemuksissa oleva kansan lähin tuki ja turva.” Yhteiskunnallisen korkeakoulun - nykyisen Tampereen yliopiston - synty 1920-luvulla edusti pappis- ja virkamieskoulutukselle vaihtoehtoista yliopistoideaa. Sen perintönä voi nähdä Suomen kansalais- ja työväenopistojen tieteellis-opinnollisen suuntautumisen ja laajalle levinneen avoimen yliopiston toiminnan.

$\mathrm{N}$ yt korkeakoulutusta "huiputetaan”, laadutetaan ja ylikansallisesti normitetaan. Mitä aikuiskasvatuksellinen näkökulma voisi merkitä tämän yleisen käskytyksen ja aikuiskasvatustieteen ja -tutkimuksen asemoimisen kannalta? Pohtiessaan yliopiston perinteistään tietoista tulevaisuutta kaoottisuuden ja kompleksisuuden oloissa englantilainen Ronald Barnett kiteyttää teoksessaan Beyond All Reason (2004) yliopiston idean yhteisölliseen järjellisyyden (reasonableness), akateemisen anteliaisuuden (generosity), institutionaalisen näppäryyden (adroitness; erityisesti moninaisuutta aktiivisesti tunnistavan johtamisen) ja oppivuuden (self-learning; erityisesti keskustelevuuden) tavoitteluun. Voisiko tätä elävää, valaisevaa ja yhteisöllistävää aikuiskasvatusta tulkita suomalaisessa perinteessä korkeakoulutuksen asettumisena osaksi aikuisuuden kokonaisvaltaista tukemista ja ylläpitämistä kulloisessakin yhteiskunnallis-historiallisessa tilanteessa?

Korkeakoulutuksen aikuiskasvatuksellisiksi normeiksi voisivat asettua sen avoimuus ihmisten tarpeille, toiveille ja luovuudelle riippumatta iästä, työ- tai koulutushistoriasta. Aikuiskasvatustieteen, -tutkimuksen ja -opetuksen alalla se voisi merkitä keskittymistä aikuisuuden ja sen ylläpitämisen yksilöllisiin ja yhteisöllisiin ominaispiirteisiin ja ehtoihin eri elämänalueilla ja elämänvaiheissa. Erityisesti aikuiskasvatuksessa niin perustutkinto- kuin jatko-opinnoistakin on muodostunut osa sen moninaisella kentällä toimijoiden yksilöllistä ja yhteisöllistä kehittymis- ja kehittämistoimintaa. Suomessa eurooppalaisen korkeakoulutusalueen (EHEA) luomiseen on viime vuosina valjastunut valtakunnallinen opettajankoulutuksen ja kasvatustieteellisen koulutuksen kehittämisen projekti (VOKKE), joka on ainutlaatuiselta näyttävällä konsensuksella rakentamassa potentiaalisesti yleiseurooppalaisia yhtenäisiä kasvatusalan (pedagogisia) opintoja.

Suunnittelutyössä suomalaisen aikuiskasvatuksen yhteiskunnallisen osallistamisen ja opillisen sivistämisen tavoitteet näyttävät murentuvan. Niin aikuiskasvatuksen kentällä ja hallinnossa kuin aikuistieteellisessä tutkimuksessa ja yliopistollisessa koulutuksessa on siten korkea aika, ellei jopa viime hetki, tiedostua ja aktivoitua sen suhteen, miten yliopiston ja korkeakoulutuksen aikuiskasvatuksellista luonnetta ollaan määrittelemässä uudelleen. Kevään reformeissa ratkaistaan pitkälle tulevaisuuteen se, saavatko aikuiskasvatuksen tieteelliset opinnot ja tutkimus eri muotoineen tilaa kasvatusalan koulutuksessa ja tunnustetaanko siinä aikuiskasvatukselle erityinen suhde toisiin tieteenaloihin ja kasvatuksen käytäntöihin. 